\title{
A Reference Value for Delta-Aminolevulinic Acid in Plasma in the Population Occupationally Unexposed to Lead
}

\begin{abstract}
To obtain a reference value for delta-aminolevulinic acid in plasma (ALAP), we determined ALA-P levels in 141 subjects (105 males and 36 females) without occupational exposure to lead. The distribution of ALA-P levels in males can be regarded to follow log-normal distribution and the geometric mean was $8.7 \mu \mathrm{g} / \mathrm{l}$ with $95 \%$ confidence interval of $6.0-12.5 \mu \mathrm{g} / \mathrm{l}$. These data would be useful as a baseline for evaluating the relationship between ALA and its biological effects.
\end{abstract}

Key words: Delta-aminolevulinic acid - Plasma - Reference value

Delta-aminolevulinic acid (ALA) is an intermediate in the heme-biosynthetic pathway and accumulates in tissues by lead exposure and in acute intermittent porphyria. ALA has been well known as a neurotoxic substance ${ }^{1,2)}$ and its carcinogenicity has been recently reported in the relation to ALA-generated reactive oxygen species ${ }^{3.4}$. The oxygen species hydroxylate deoxyguanosine residues in DNA and produce hydroxy-2'-deoxyguanosine, which induces G-T transversion. Thus, the knowledge of the ALA concentration in the tissue such as plasma would be very important not only in industrial health but also in the mechanism of chemical carcinogenesis. For several years, the sensitive methods of determining ALA in plasma or blood by fluorometric method using high-performance liquid chromatography (HPLC) have been developed ${ }^{5-8}$; however, there is few study which collected the sufficient number of normal subjects and determined not only ALA in plasma (ALA-P) level but also blood lead concentration ( $\mathrm{Pb}-\mathrm{B})$. In this study, we determined the concentration of ALA-P and $\mathrm{Pb}-\mathrm{B}$ in large numbers of occupationally unexposed population and reported the reference value for ALA-P.

Venous blood treated with EDTA-2K was obtained from 152 subjects who did not deal with lead in their work. The workers who have had a special medical examination for lead poisoning were excluded from this study. Blood samples were collected in the physical examinations. Two workers were found to take medicine by a medical checkup. Four workers showed abnormal levels in hematocrit. Five workers whose blood were hemolyzed during sampling were also excluded. Therefore, those 11 subjects were excluded from this study. A total number of analysis was 141 for 105 males and 36 females, consisting of 42 workers of electrical appliance manufacture, 63 drivers, 33 bus conducteresses and 3 clerks.

Address for correspondence: Yoko Morita, National Institute of Industrial Health, 21-1, Nagao

6-chome, Tama-ku, Kawasaki-shi, Kanagawa 214, Japan. 
Plasma was separated from whole blood immediately after sampling, and stored at $-80^{\circ} \mathrm{C}$ until analysis. ALA-P was determined as described previously ${ }^{8}$. $\mathrm{Pb}-$ $\mathrm{B}$ was determined by flameless atomic absorption spectrometry.

Figure 1 shows the histograms of ALA-P levels in 105 male and 36 female subjects. The distribution pattern of male ALA-P levels was tested by skewness (b1) and krutosis (b2). The original ALA-P data did not fit for normal distribution ( $\mathrm{b} 1=1.06, \mathrm{~b} 2=5.44 ; \mathrm{p}<0.01$, respectively). When the ALA-P values were converted to logarithm, the distribution of ALA-P in males can be regarded to
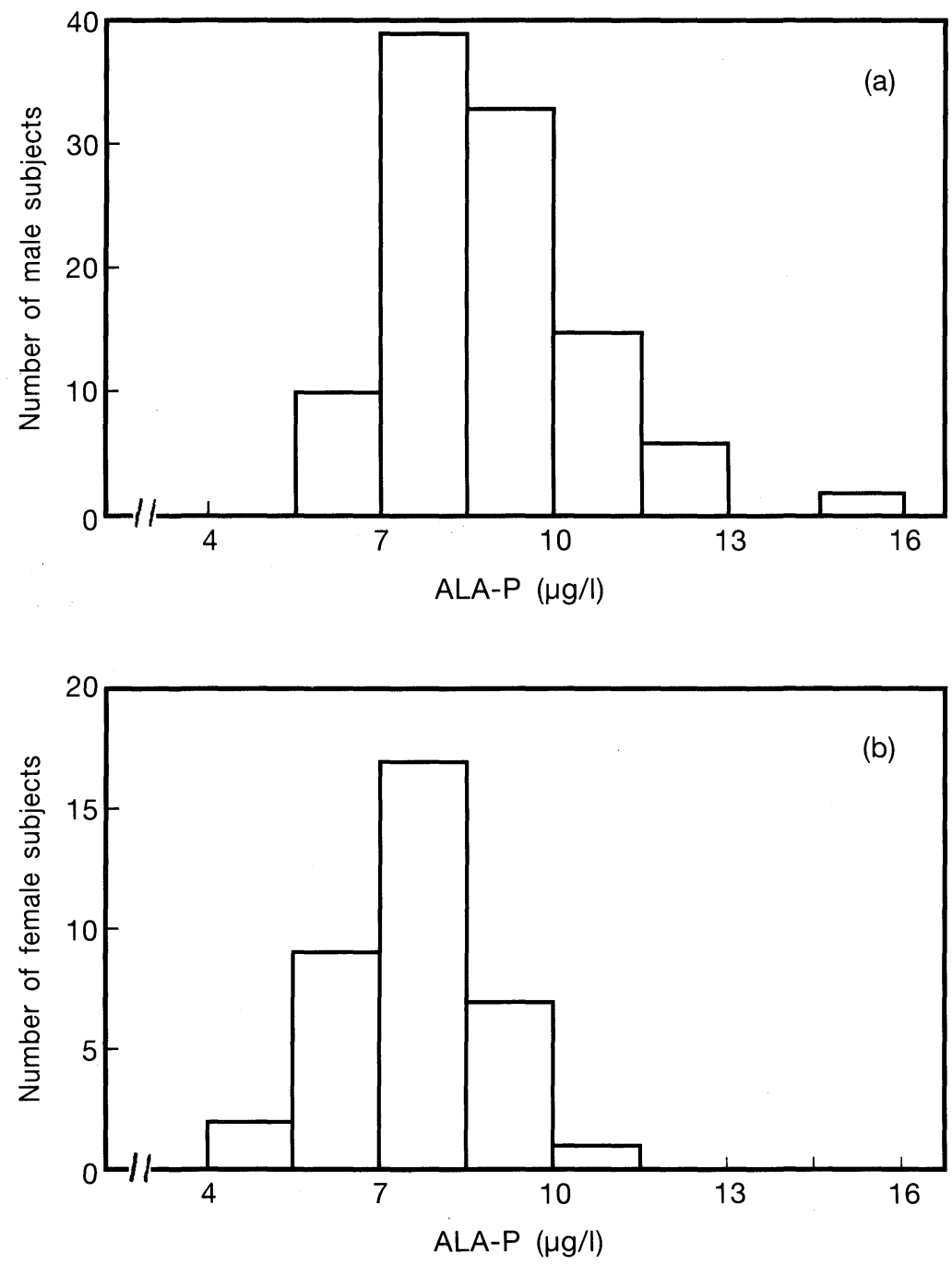

Fig. 1. Distribution of delta-aminolevulinic acid in plasma (ALA-P) in 105 males (a) and in 36 females (b). 
follow log-normal distribution ( $\mathrm{b} 1=0.30, \mathrm{~b} 2=3.60 ; \mathrm{p}>0.05$, respectively). The geometric mean of ALA-P was $8.7 \mu \mathrm{g} / \mathrm{l}$ and the $95 \%$ confidence interval was 6.0$12.5 \mu \mathrm{g} / \mathrm{l}$. The distribution of ALA in urine (ALA-U) in healthy urban males has been reported to follow log-normal distribution ${ }^{9}$. For the ALA-P levels in females, comments could not be given in detail, because the sample number was only 36 and their ages were distributed to younger population in this study.

Table 1 shows the ages and concentrations of ALA-P and Pb-B in the subjects in this study. Mean Pb-B levels of both genders were less than $5 \mu \mathrm{g} / \mathrm{dl}$, which was coincident with the value reported by Watanabe et al. ${ }^{10)}$ The mean \pm SD of ALA$\mathrm{P}$ levels in males were reported to be $8.2 \pm 4.7 \mu \mathrm{g} / \mathrm{l}(\mathrm{n}=32)^{7)} 8.6 \pm 1.3 \mu \mathrm{g} / \mathrm{l}$ $(\mathrm{n}=26)^{8}$. Although the $\mathrm{Pb}-\mathrm{B}$ levels were not determined in these two studies, both the ALA-P levels ${ }^{7}{ }^{8)}$ were nearly equal to the value in the present study. There was no study which determined ALA-P levels in females occupationally unexposed to lead. In the present study, both ALA-P and $\mathrm{Pb}-\mathrm{B}$ levels in females were statistically lower than those in males ( $\mathrm{p}<0.01$, by Welch's test). Taguchi et al. ${ }^{11)}$ reported that ALA$\mathrm{U}$ levels in females were lower than those in males in subjects occupationally unexposed to lead but when the urine was corrected for creatinine, ALA-U levels in females were higher than those in males. In this study, no significant correlation was found between ALA-P and $\mathrm{Pb}-\mathrm{B}$ or age in each gender.

We previously determined both levels of ALA-P and Pb-B in 191 male lead workers and reported that the no effect level of $\mathrm{Pb}-\mathrm{B}$ for increasing ALA-P might be around $5 \mu \mathrm{g} / \mathrm{dl}^{12}$. This previous data are basically consistent with the present results because the number of subjects whose $\mathrm{Pb}-\mathrm{B}$ levels were more than $5 \mu \mathrm{g} / \mathrm{dl}$ was only 18 and the highest level of $\mathrm{Pb}-\mathrm{B}$ was as low as $6.9 \mu \mathrm{g} / \mathrm{dl}$ in this study. It is suggested that ALA-P levels in male adults are not associated with $\mathrm{Pb}-\mathrm{B}$ levels in the normal population whose mean Pb-B levels were less than $5 \mu \mathrm{g} / \mathrm{dl}$ as seen in Japan.

This is the first report of a reference value for ALA-P levels in large numbers of male adults whose mean $\mathrm{Pb}-\mathrm{B}$ levels were less than $5 \mu \mathrm{g} / \mathrm{dl}$. This result would be useful as a baseline for evaluating the relationship between ALA and its biological effects. This study have to be followed by extended surveys for female.

Table 1. Ages and concentrations of blood lead (Pb-B) and delta-aminolevulinic acid in plasma (ALA-P) in males and females.

\begin{tabular}{llcl}
\hline & & Males $(\mathbf{n}=\mathbf{1 0 5})$ & Females $(\mathbf{n}=\mathbf{3 6})$ \\
\hline Age & AM & $40.6 \pm 8.7(20-60)$ & $22.5 \pm 5.3(18-40)$ \\
ALA-P $(\mu \mathrm{g} / \mathrm{l})$ & $\mathrm{AM}$ & $8.8 \pm 1.7(5.7-15.6)$ & $7.6 \pm 1.3(5.2-10.8)$ \\
& $\mathrm{GM}$ & $8.7 \pm 1.2$ & $7.5 \pm 1.2$ \\
$\mathrm{~Pb}-\mathrm{B}(\mu \mathrm{g} / \mathrm{dl})$ & $\mathrm{AM}$ & $3.9 \pm 1.2(1.8-6.9)$ & $2.4 \pm 0.7(1.1-4.3)$ \\
& $\mathrm{GM}$ & $3.7 \pm 1.4$ & $2.3 \pm 1.3$ \\
\hline
\end{tabular}

AM: Arithmetic mean \pm SD (Range).

GM: Geometric mean \pm SD. 


\section{Si. . . \\ REFERENCES}

1) Muller WE, Synder SH. $\delta$-Aminolevulinic acid: Influences on synaptic GABA receptor binding may explain CNS symptoms of porphyria. Ann Neurol 1977; 2: 340-2.

2) Thunell S, Holmberg L, Lundgen J. Aminolaevulinate dehydratase porphyria in infancy. A clinical and biochemical study. J Clin Chem Clin Biochem 1987; 25: 5-14.

3) Fraga CG, Onuki J, Lucesoli F, Bechara EJH, diMascio P. 5-aminolevulinic acid mediates the in vivo and in vitro formation of 8-hydroxy-2'-deoxyguanosine in DNA. Carcinogenesis 1994; 10: $2241-4$

4) Hermes-Lima M, Valle VGR, Vercesi AE, Bechara EJH. Damage to rat liver mitochondria promoted by $\delta$-aminolevulinic acid-generated reactive oxygen species. Connections with acute intermittent porphyria and lead-poisoning. Biochim Biophys Acta 1991; 1056: 57-63.

5) Hosoda K, Sakurai H, Omae K, Kamakura M, Satoh T. $\delta$-aminolevulinic acid in blood as an indicator of early health effect of lead. Jpn J Ind Health 1989; 31: 240-1.

6) Takebayashi T, Omae K, Hosoda K, Satoh T, Hamaguchi T, Sakurai H. Evaluation of $\delta$ aminolevulinic acid in blood of workers exposed to lead. Br J Ind Med 1993; 50: 49-5.

7) Tomokuni K, Ichiba M, Hirai Y. High-sensitive determination of $\delta$-aminolevulinic acid (ALA) in serum or plasma. Porphyrins 1992; 1: 299-304.

8) Morita Y, Araki S, Sakai T, Araki T, Masuyama Y. Determination of delta-aminolevulinic acid in plasma using high-performance liquid chromatography: a sensitive indicator of lead effects. Ind Health 1994; 32: 85-96.

9) Kasahara A. Studies on urinary $\delta$-aminolevulinic acid excretion of healthy urban male population. Osaka City Med J 1965; 11: 99-117.

10) Watanabe T, Fujita H, Koizumi A, Chiba K, Miyasaka M, Ikeda M. Baseline level of blood lead concentration among Japanese farmers. Arch Environ Health 1985; 40: 170-6.

11) Taguchi T, Suzuki S, Yokohashi G. Normal levels of lead, $\delta$-aminolevulinic acid and coproporphyrin in spot urines. Jpn J Ind Health 1970; 12: 482-3.

12) Sakai T, Morita Y. $\delta$-Aminolevulinic acid in plasma or whole blood as a sensitive indicator of lead effects, and its relation to the heme-related parameters. Int Arch Occup Environ Health (in (press).

1) National Institute of Industrial Health, 21-1, Nagao 6-chome, Tama-ku, Kawasaki-shi, Kanagawa 214, Japan.

2) Center of Occupational Medicine, Tokyo Labor Accident Hospital, 13-21, Omoriminami-4, Ota-ku, Tokyo 143, Japan.

\author{
Yoko MORITA ${ }^{1}$, \\ Tadashi SAKAI', \\ Takaharu ARAKI'), \\ Koichi SUZUKI ${ }^{3 \text {, }}$, \\ Kenichi ODA ${ }^{3 \text {, }}$ \\ Shunichi ARAKI ${ }^{4)}$ and \\ Yoshiaki MASUYAMA ${ }^{2)}$
}

3) Derpartment of Health Examination, Kanto Labor Accident Hospital, '2035, Kizukisumiyoshi-cho, Nakahara-ku, Kawasaki-shi, Kanagawa 211, Japan.

4) Department of Public Health, Faculty of Medicine, The University of Tokyo, 3-1, Hongo-7, Bunkyo-ku, Tokyo 113, Japan.

(Received October 19, 1995 and in revised form November 30, 1995) 